\title{
TO COMPARE THE POSTOPERATIVE ANALGESIC EFFICACY OF LEVOBUPIVACAINE AND ROPIVACAINE USING TRANSVERSUS ABDOMINIS PLANE BLOCK IN PATIENTS UNDERGOING INGUINAL HERNIA SURGERIES
}

Preeti Goyal', Rahul Meda²

${ }_{1}^{1}$ Associate Professor, Department of Anaesthesia, Gajra Raja Medical College, Gwalior.

${ }^{2}$ Postgraduate Student, Department of Anaesthesia, Gajra Raja Medical College, Gwalior.

\section{ABSTRACT}

\section{BACKGROUND}

Transversus abdominis plane block is a novel approach for postoperative analgesia after abdominal surgeries.

The aim of the study was to evaluate the postoperative analgesic efficacy of levobupivacaine and ropivacaine using transversus abdominis plane block after elective inguinal hernia surgeries.

\section{MATERIAL AND METHODS}

Ninety adult patients of ASA grade I and II were randomly divided into group L receiving TAP block with $0.25 \% 20 \mathrm{~mL}$ levobupivacaine, group R receiving TAP block with. 25\% 20 mL ropivacaine and control group receiving NS $20 \mathrm{~mL}$ after completion of surgery. All the patients were assessed for post-operative pain and rescue analgesic consumption at $10 \mathrm{~min}$., $30 \mathrm{~min}$., $1 \mathrm{hour}, 4$ hours, 8 hours, 12 hours and 24 hours' time points.

\section{RESULTS}

Patients receiving TAP block with ropivacaine or levobupivacaine had significantly lower pain scores as compared to control group at $10 \mathrm{~min} ., 30 \mathrm{~min} ., 1 \mathrm{hr}$., $4 \mathrm{hr}$., $8 \mathrm{hr}$., $12 \mathrm{hr}$. and $24 \mathrm{hr}$. However, levobupivacaine provided significantly better analgesia as compared to ropivacaine.

\section{CONCLUSION}

TAP block with levobupivacaine or ropivacaine provides effective analgesia in postoperative period.

\section{KEYWORDS}

Analgesia, Levobupivacaine, Ropivacaine, Transversus Abdominis Plane Block.

HOW TO CITE THIS ARTICLE: Goyal P, Meda R. To compare the postoperative analgesic efficacy of levobupivacaine and ropivacaine using transversus abdominis plane block in patients undergoing inguinal hernia surgeries. J. Evolution Med. Dent. Sci. 2017;6(14):1088-1092, DOI: 10.14260/Jemds/2017/236

BACKGROUND
The word pain is derived from the Greek term poine (penalty). ${ }^{1}$ The International Association of Pain defines pain as an unpleasant sensory and emotional experience associated with actual or potential tissue damage. ${ }^{2}$

Postoperative pain is defined as a condition of tissue injury together with muscle spasm after surgery. ${ }^{3}$ Postoperative analgesia is one of the most important factors of perioperative anaesthetic management. The main aim is to improve the comfort and satisfaction of the patient, to facilitate functional recovery, reduce morbidity and promote rapid discharge from hospital. ${ }^{4}$

Traditionally, analgesia for abdominal surgery is provided either by systemic drugs such as opioids, ketamine, nonsteroidal anti-inflammatory drugs, alpha- 2 agonists, and paracetamol or by epidural anaesthesia. ${ }^{5}$

TAP block is an alternative, simple to perform and effective peripheral abdominal field block that blocks the lower intercostal ( $\left.\mathrm{T}_{7}-\mathrm{T}_{11}\right)$, ilioinguinal and hypogastric nerves. ${ }^{6}$

Financial or Other, Competing Interest: None.

Submission 23-01-2017, Peer Review 06-02-2017,

Acceptance 08-02-2017, Published 16-02-2017.

Corresponding Author:

Dr. Preeti Goyal,

\#N-12 Chetak Puri, Gwalior.

E-mail: drpreetiravigoyal@gmail.com

DOI: $10.14260 / j e m d s / 2017 / 236$

(c) (i) (\$) $\odot$
Transversus abdominis plane block (TAP) is a novel technique that improves postoperative pain control after abdominal surgery. It involves block of nerves of anterior abdominal wall by injection of long acting local anaesthetic solution between internal oblique and transversus abdominis muscle. It has been effective in many clinical settings such as abdominoplasty, caesarean section, prostatectomy and colorectal surgery. 7,8

The present study aimed to assess and compare the effects of Levobupivacaine and Ropivacaine for postoperative analgesia using transversus abdominis plane block in patients undergoing inguinal hernia repair under subarachnoid block.

\section{MATERIALS AND METHODS}

After taking approval from ethical committee and written informed consent, 90 adult patients of ASA Grade I and II scheduled for inguinal hernia surgeries were recruited in this randomised double blind controlled clinical trial. Unwilling patients, patients with $\mathrm{BMI}<18$ or $>35 \mathrm{Kg} / \mathrm{m}^{2}$, compromised liver and renal functions, severe cardiovascular respiratory disease, known allergy to local anaesthetic and infection at the injection site were excluded from the study.

Patients were blinded by the sealed envelope technique and observer anaesthesiologist was kept unaware of which drug was injected to which patient thus avoiding observer bias. Standard monitoring was used. Baseline parameters such as heart rate, continuous electrocardiogram, noninvasive blood pressure, $\mathrm{SpO}_{2}$ were noted down. Selected 
90 patients were randomly divided into three groups of 30 each depending upon the drug given.

Group L- Injection levobupivacaine hydrochloride $20 \mathrm{~mL}$, $0.25 \%$.

Group R- Injection ropivacaine hydrochloride $20 \mathrm{~mL}$, $0.25 \%$.

Group C- 20 mL of normal saline.

The anaesthesiologist who prepared the drug was not involved in the data collection. Upon arrival of the patient in the operation theatre, intravenous access with $18 \mathrm{G}$ cannula established. $500 \mathrm{~mL}$ of crystalloid infusion started. After aseptic precautions, cleaning, painting, and draping done under left lateral position. SAB is induced with $23 \mathrm{G}$ spinal needle in $\mathrm{L}_{3}-\mathrm{L}_{4}$ intervertebral space. After confirmation of free flow of CSF, $3.5 \mathrm{~mL}$ of $0.5 \%$ bupivacaine (Heavy) is injected intrathecally. All vital parameters were recorded intraoperatively at different time points. After completion of surgery, the lumbar triangle of Petit located just anterior to latissimus dorsi muscle was identified by palpating the iliac crest in an anterior to posterior direction until the edge of latissimus dorsi was felt. The skin was pierced just cephalic to the iliac crest over the triangle of Petit with a blunt $18 \mathrm{G}$ Tuohy needle. The needle was advanced perpendicular to the skin in the coronal plane until the first resistance of external oblique muscle was encountered. Gentle advancement of the needle resulted in pop sensation as the needle entered the plane between external and internal oblique fascial layers. A second resistance was felt as the needle passed through the internal oblique muscle. A second loss of resistance was felt when the needle reaches the transversus abdominis fascial plane between the internal oblique and transversus abdominis muscle. A test dose of $1 \mathrm{~mL}$ was injected to confirm the needle tip placement within the neurovascular plane. After this one of the study drug was injected after careful aspiration to exclude vascular puncture.

Postoperative analgesia was assessed with VAS scale. (0-10 with 0 -No Pain to 10 -Very severe pain)

The time of administration of rescue analgesic in the form of injection tramadol $2 \mathrm{mg} / \mathrm{kg}$ was noted when VAS was $>4$. Total dose of tramadol consumed in 24 hours was also recorded.

Adverse effects such as hypotension, bradycardia, nausea, vomiting were also noted during 24 hours. Any complication of the technique like local site infection, haematoma formation, signs of local anaesthetic toxicity, and bowel perforation were observed. The observations recorded in all the groups were tabulated and statistical analysis carried out by using statistical software SPSS 17 . Student " $\mathrm{t}$ " test for intergroup comparison was used. $\mathrm{P}$ value $<0.05$ was taken statistically significant whereas P-value $<0.01$ taken to be highly significant.

\section{RESULTS}

\begin{tabular}{|c|c|c|c|c|c|c|}
\hline \multirow{2}{*}{ Variable } & \multicolumn{2}{|c|}{$\begin{array}{c}\text { Group L } \\
(n=30)\end{array}$} & \multicolumn{2}{|c|}{$\begin{array}{c}\text { Group R } \\
(n=30)\end{array}$} & \multicolumn{2}{|c|}{$\begin{array}{c}\text { Group C } \\
(n=30)\end{array}$} \\
\hline & \multicolumn{2}{|c|}{ Mean \pm SD } & \multicolumn{2}{|c|}{ Mean \pm SD } & \multicolumn{2}{|c|}{ Mean \pm SD } \\
\hline Age (Yrs.) & \multicolumn{2}{|c|}{$40.9 \pm 11.6$} & \multicolumn{2}{|c|}{$40.8 \pm 11.54$} & \multicolumn{2}{|c|}{$39.6 \pm 12.5$} \\
\hline Weight (Kg) & \multicolumn{2}{|c|}{$39.6 \pm 12.5$} & \multicolumn{2}{|c|}{$60.4 \pm 6.53$} & \multicolumn{2}{|c|}{$57.4 \pm 7.23$} \\
\hline $\begin{array}{c}\text { Duration of } \\
\text { Surgery (Min.) }\end{array}$ & \multicolumn{2}{|c|}{$58.23 \pm 6.47$} & \multicolumn{2}{|c|}{$58.23 \pm 6.47$} & \multicolumn{2}{|c|}{$57.4 \pm 7.23$} \\
\hline ASA Grade I & 23 & 76.6 & 21 & 70 & 20 & 66.6 \\
\hline ASA Grade II & 7 & 23.4 & 9 & 30 & 10 & 33.4 \\
\hline
\end{tabular}

\begin{tabular}{|c|c|c|c|c|c|}
\hline \multirow{2}{*}{ Variable } & \multicolumn{2}{|c|}{$\begin{array}{c}\text { Group L } \\
(\mathbf{n}=\mathbf{3 0 )}\end{array}$} & \multicolumn{2}{c|}{$\begin{array}{c}\text { Group R } \\
(\mathbf{n}=\mathbf{3 0 )}\end{array}$} & \multicolumn{2}{c|}{$\begin{array}{c}\text { Group C } \\
\mathbf{( n = 3 0 )}\end{array}$} \\
\cline { 2 - 7 } & \multicolumn{2}{|c|}{ Mean \pm SD } & \multicolumn{2}{c|}{ Mean \pm SD } & \multicolumn{2}{c|}{ Mean \pm SD } \\
\hline VAS Score & $5.13 \pm 0.12$ & \multicolumn{2}{|c|}{$5.77 \pm 0.16$} & \multicolumn{2}{c|}{$6.64 \pm 0.41$} \\
\hline & \multicolumn{2}{|c|}{ Group L vs. R } & \multicolumn{2}{|c|}{ Group R vs. C } & \multicolumn{2}{c|}{ Group L vs. C } \\
\hline & $\begin{array}{c}\mathrm{t} \\
\mathrm{y}\end{array}$ & $\begin{array}{c}\mathrm{t} \\
\mathrm{p}\end{array}$ & $\begin{array}{c}\mathrm{p} \\
\mathrm{t}\end{array}$ & $\begin{array}{c}\mathrm{p} \\
\text { Value }\end{array}$ & Value \\
\hline
\end{tabular}

Table 2 shows the Mean $( \pm S D)$ VAS score in all the groups. The mean VAS score in group I was $5.13 \pm 0.12$, group II was $5.77 \pm 0.16$ and group III was $6.64 \pm 0.41$ respectively.

\begin{tabular}{|c|c|c|c|c|c|c|}
\hline \multirow[t]{2}{*}{ Variable } & \multicolumn{2}{|c|}{$\begin{array}{c}\text { Group L } \\
(n=30)\end{array}$} & \multicolumn{2}{|c|}{$\begin{array}{c}\text { Group R } \\
(n=30)\end{array}$} & \multicolumn{2}{|c|}{$\begin{array}{c}\text { Group C } \\
(n=30)\end{array}$} \\
\hline & \multicolumn{2}{|c|}{ Mean \pm SD } & \multicolumn{2}{|c|}{ Mean \pm SD } & \multicolumn{2}{|c|}{ Mean \pm SD } \\
\hline $\begin{array}{c}\text { Time for first } \\
\text { Rescue Analgesia } \\
\text { (Min.) }\end{array}$ & \multicolumn{2}{|c|}{$208.8 \pm 27.02$} & \multicolumn{2}{|c|}{$155 \pm 39.53$} & \multicolumn{2}{|c|}{$8.72 \pm 6.19$} \\
\hline \multirow[t]{2}{*}{ Variable } & \multicolumn{2}{|c|}{ Group L vs. R } & \multicolumn{2}{|c|}{ Group R vs. C } & \multicolumn{2}{|c|}{ Group L vs. C } \\
\hline & $\begin{array}{c}\mathrm{t} \\
\text { value }\end{array}$ & $\begin{array}{c}\mathrm{p} \\
\text { value }\end{array}$ & \begin{tabular}{|c|}
$\mathrm{t}$ \\
value \\
\end{tabular} & $\begin{array}{c}\mathrm{p} \\
\text { value }\end{array}$ & \begin{tabular}{|c|}
$\mathrm{t}$ \\
value
\end{tabular} & $\begin{array}{c}\mathrm{p} \\
\text { value }\end{array}$ \\
\hline $\begin{array}{c}\text { Time for first } \\
\text { Rescue Analgesia } \\
\text { (Min.) }\end{array}$ & 6.36 & $0.00 \$$ & 20.67 & $0.00 \$$ & 40.83 & $0.00 \$$ \\
\hline 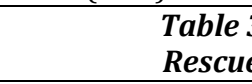 & $M$ & $\pm S L$ & III & $\Gamma_{0}$ & & \\
\hline
\end{tabular}

Table 3 shows the Mean $( \pm S D)$ time of first rescue analgesia in all three groups, the mean duration of analgesia in group I was $208.8 \pm 27.02$ min., group II was $155 \pm 39.53$ min. and group III was $8.72 \pm 6.19 \mathrm{~min}$. respectively.

Table 3 shows the statistical comparison of time for first rescue analgesia among all three groups and was found significant $(\mathrm{p}<0.05)$ in group I and II as compared to group III.

\# p >0.05 (Insignificant).

$\$ p<0.05$ (Significant).

\begin{tabular}{|c|c|c|c|c|c|c|}
\hline \multirow[t]{2}{*}{ Variable } & \multicolumn{2}{|c|}{$\begin{array}{c}\text { Group L } \\
(n=30)\end{array}$} & \multicolumn{2}{|c|}{$\begin{array}{c}\text { Group R } \\
(n=30)\end{array}$} & \multicolumn{2}{|c|}{$\begin{array}{c}\text { Group C } \\
(n=30)\end{array}$} \\
\hline & \multicolumn{2}{|c|}{ Mean \pm SD } & \multicolumn{2}{|c|}{ Mean \pm SD } & \multicolumn{2}{|c|}{ Mean \pm SD } \\
\hline $\begin{array}{c}\text { Total analgesic } \\
\text { Dose (mg) }\end{array}$ & \multicolumn{2}{|c|}{$\begin{array}{c}253.1 \pm \\
50.78\end{array}$} & \multicolumn{2}{|c|}{$\begin{array}{c}312.50 \pm \\
33.60 \\
\end{array}$} & \multicolumn{2}{|c|}{$\begin{array}{c}396.8 \pm \\
40\end{array}$} \\
\hline \multirow[t]{2}{*}{ Variable } & \multicolumn{2}{|c|}{$\begin{array}{l}\text { Group L } \\
\text { vs. R }\end{array}$} & \multicolumn{2}{|c|}{$\begin{array}{c}\text { Group-R } \\
\text { Vs. C }\end{array}$} & \multicolumn{2}{|c|}{$\begin{array}{l}\text { Group L } \\
\text { Vs. C }\end{array}$} \\
\hline & $\begin{array}{c}\mathrm{t} \\
\text { value }\end{array}$ & $\begin{array}{c}\mathrm{p} \\
\text { value }\end{array}$ & $\begin{array}{c}\mathrm{t} \\
\text { value }\end{array}$ & \begin{tabular}{|c|}
$\mathrm{p}$ \\
value
\end{tabular} & $\begin{array}{c}\mathrm{t} \\
\text { value }\end{array}$ & $\begin{array}{c}\mathrm{p} \\
\text { value }\end{array}$ \\
\hline Total Analgesic Dose & 5.52 & $0.00 \$$ & 9.13 & $0.00 \$$ & 12.58 & $0.00 \$$ \\
\hline
\end{tabular}

Table 4 shows the Mean $( \pm S D)$ of total analgesic consumption at 24 hours in all three groups, the mean duration of analgesic dose in group I was $253.1 \pm 50.70 \mathrm{mg}$, group II was $312.50 \pm 33.60 \mathrm{mg}$ \& group III was $396.8 \pm 40 \mathrm{mg}$ respectively.

Table 4 also shows the statistical comparison of total analgesic dose at 24 hours among all three groups and was found significant ( $p$ value $<0.05$ ) in group I and II as compared to group III.

$\begin{array}{lllll}\text { \# } & \mathrm{p}>0.05 & \text { (Insignificant). } \quad \$ \quad \mathrm{p}<0.05 \quad \text { (Significant) }\end{array}$ 


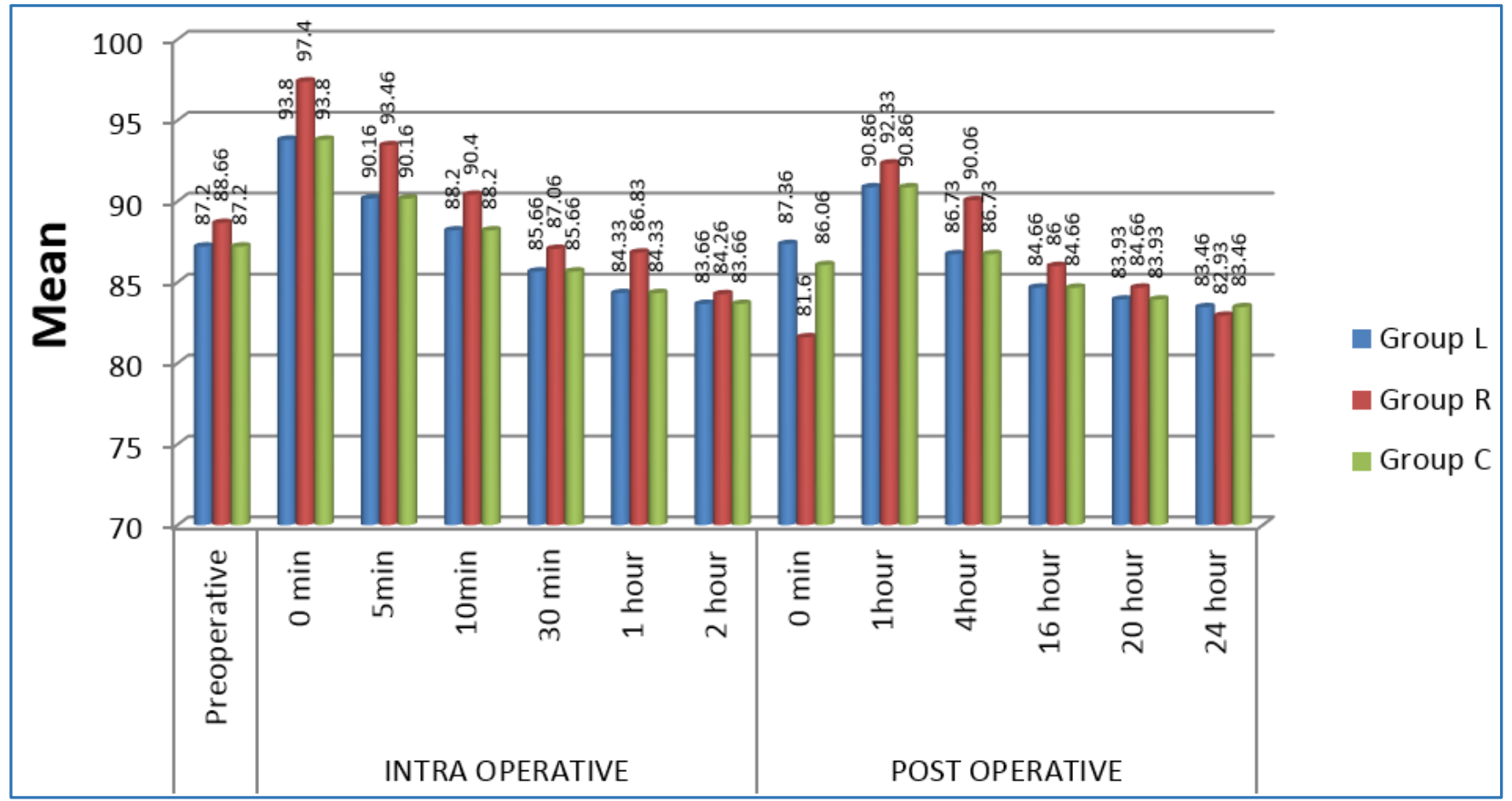

Graph 1. Perioperative Pulse Rate Mean in Three Groups

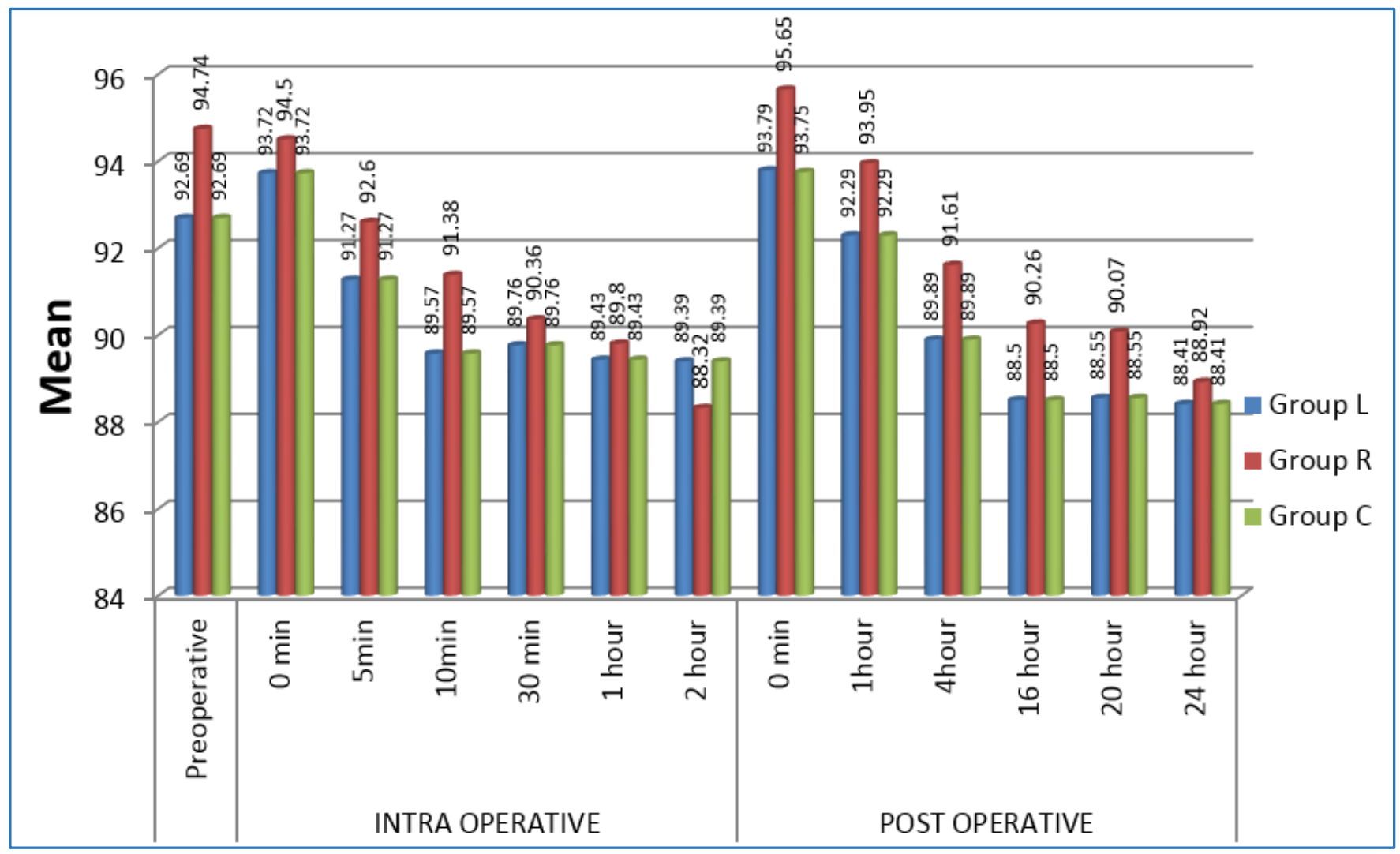

Graph 2. Perioperative Mean Arterial Blood Pressure Mean in Three Groups

Ninety patients were subjected for trial and data collected were analysed. The three groups were comparable in terms of baseline demographic parameters (Age, weight), ASA Grade, duration of surgery and anaesthesia, perioperative haemodynamic parameters (Pulse rate, systolic and diastolic blood pressure, respiratory rate). A summary of baseline characteristics of the patients has been shown in Table 1.
VAS scores in the postoperative period were significantly reduced in patients who received TAP block with either levobupivacaine or ropivacaine as compared to control group as shown in Table no. 2 (Group L Mean \pm SD 5.14 \pm 0.13 , Group $\mathrm{R} 5.77 \pm 0.16$ and Group $\mathrm{C} 6.67 \pm 0.41$ ). Also there is a significant reduction in VAS score in patients who received levobupivacaine as compared to patients receiving ropivacaine. 
Time for first rescue analgesia is significantly prolonged in group L and group $\mathrm{R}$ as compared to control group. (Group L 209.3 \pm 27.25 , Group R 152 \pm 39.58 , Group C 8.6 \pm 5.8 ). Also there is a statistically significant prolongation of time of first rescue analgesia in levobupivacaine group as compared to ropivacaine group (Table 3 ).

Significantly increased dose of tramadol is consumed in group $C$ as compared to group $L$ and $R$ (Group L 253.3 \pm 50.74 , Group R 313.3 \pm 34.57 , Group C 396.6 \pm 41.38 ). The patients who received levobupivacaine requires significantly less tramadol in postoperative period as compared to patients who received ropivacaine (Table 4).

There was statistically insignificant difference between the three groups in terms of median values of intraoperative and postoperative pulse rate, mean arterial blood pressure (Graph I and II.)

Only one patient in group $\mathrm{L}$, and 2 patients in group $\mathrm{C}$ had nausea in postoperative period, $16.6 \%$ patients in group $\mathrm{L}$, $6.67 \%$ in group $\mathrm{R}$ and $10 \%$ patients in group $\mathrm{C}$ suffered shivering. None of the patients suffered hypotension, bradycardia, dyspnoea, chest pain and dysrhythmia. None of the patient had complication related to TAP block.

\section{DISCUSSION}

Pain has been found to be one of the three most common medical causes of delayed discharge after ambulatory surgery, the other two being drowsiness and nausea/vomiting. Despite this overwhelming rationale for postoperative pain control, the clinical reality is unfortunately still far from satisfactory. ${ }^{9}$

Postoperative analgesia is one of the main concerns of both the surgeons and the patients after every surgery. Effective postoperative pain control is an essential component of the care of the surgical patient. Inadequate pain control, apart from being inhumane, may result in increased morbidity or mortality. ${ }^{10}$ Traditionally, opioids are the mainstay of systemic analgesia for the treatment of moderate to severe postoperative pain. Unfortunately, opioid related side effects limit their use in many patients. Analgesics that act by different mechanisms and at different receptor sites can be combined to produce additive pain relief and can reduce opioid use.

TAP block is a local anaesthetic block used to provide analgesia to anterior and lateral abdominal wall. TAP block after surgery has been demonstrated to provide safe and effective postoperative pain relief with better quality of pain control, decreased incidence of side effects, and higher degree of patient satisfaction than patients controlled by analgesia with opioid drugs. ${ }^{11}$

Racemic bupivacaine is gradually being replaced by ropivacaine or levobupivacaine. This change is driven by the reduced potential for systemic toxicity and the lower risk of motor blockade. ${ }^{12}$ Studies proved that a concentration of $0.25 \% 20 \mathrm{~mL}$ levobupivacaine provided best postoperative analgesia given by transversus abdominis plane block. ${ }^{13}$ The volume of LA to be deposited was derived from previous studies. ${ }^{14-17}$ TAP block with plain solution of levobupivacaine $0.25 \%$ provides more effective pain relief as compared to ropivacaine in the postoperative period. The time to first analgesic request is significantly prolonged with levobupivacaine and ropivacaine as compared to control group. The findings are consistent with various other studies.18,19 Although none of the studies compared levobupivacaine and ropivacaine in TAP block for postoperative analgesia but their analgesic efficacy is compared by pre-incisional local infiltration after laparoscopic cholecystectomy by Papagiannopoulou $\mathrm{P}$ et al 20 which also showed similar results as our study but the concentration of ropivacaine and levobupivacaine used were $1 \%$ and $0.5 \%$ respectively.

In our study, the total dose of tramadol consumption in 24 hours postoperatively is lower in levobupivacaine group as compared to ropivacaine group. Similar results are observed by other studies. ${ }^{13,20-22}$ Significant reduction of VAS score is observed in patients who received TAP block with either levobupivacaine or ropivacaine as compared to control group. The results of our study are consistent with the findings of other studies. ${ }^{18,23-27}$

The haemodynamic parameters remained stable perioperatively with both drugs used in TAP block. The results are in accordance with other studies. ${ }^{21,27-30}$

The present study has certain limitations. The pain scores at movement have not been taken into account. Evaluation of sensory block level was not undertaken because the block was performed under the effect of subarachnoid block.

\section{CONCLUSION}

Although TAP block with $0.25 \%$ ropivacaine or $0.25 \%$ levobupivacaine provided adequate analgesia postoperatively in patients undergoing inguinal hernia surgeries, levobupivacaine provided significantly superior analgesia as compared to ropivacaine.

\section{REFERENCES}

[1] Larson MS. History of anaesthetic practice. In: Miller RD, Fleisher LA, Eriksson LI, (eds). Miller's Anesthesia. $7^{\text {th }}$ edn. Philadelphia: Elsevier 2009:3-43.

[2] Merskey H, Bogduk N. Classification of chronic pain. $2^{\text {nd }}$ edn. Seattle: IASP Press, 1994:p 1.

[3] Ceyhan D, Gulec MS. Is postoperative pain only a nociceptive pain? Agri 2010;22(2):47-52.

[4] Mishra AK, Afzal M, Mookerjee SS, et al. Pre-emptive analgesia, recent trends and evidences. Indian J of Pain 2013;27(3):114-20.

[5] Sharma P, Chand T, Saxena A, et al. Evaluation of postoperative analgesic efficacy of transversus abdominis plane block after abdominal surgery: a comparative study. J Nat Sci Biol Med 2013;4(1):17780.

[6] Salman AE, Yetisir F, Yurekli B, et al. The efficacy of the semi-blind approach of transversus abdominis plane block on postoperative analgesia in patients undergoing inguinal hernia repair: a prospective randomized double-blind study. Local Reg Anaesth 2013;6:1-7.

[7] Rafi AN. Abdominal field block: a new approach via the lumbar triangle. Anaesthesia 2001;56(10):1024-6.

[8] Hebbard P, Fujiwara Y, Shibata Y, et al. Ultrasoundguided transversus abdominis plane (TAP) block. Anaesth Intensive Care 2007;35(4):616-7.

[9] Vadivelu N, Mitra S, Narayan D. Recent advances in postoperative pain management. Yale J Biol Med 2010;83(1):11-25. 
[10] Kamtane RA, Shailendra D, Prasuna G, et al. Safety and efficacy of tramadol compared to diclofenac in relieving postoperative pain. JEBMH 2015;21:310411.

[11] Garimella V, Cellini C. Postoperative pain control. Clin Colon Rectal Surg 2013;26(3):191-6.

[12] Bajwa SJ, Kaur J. Clinical profile of levobupivacaine in regional anaesthesia: a systematic review. J Anaesthesiol Clin Pharmacol 2013;29(4):530-9.

[13] Cansiz KH, Yedekci AE, Sen H, et al. The effect of ultrasound guided transversus abdominis plane block for cesarean delivery on postoperative analgesic consumption. Gulhane Med J 2015;57(2):121-4.

[14] McDonnell JG, O'Donnell B, Curley G, et al. The analgesic efficacy of transversus abdominis plane block after abdominal surgery: a prospective randomized controlled trial. Anaesth Analg 2007;104(1):193-7.

[15] Niraj G, Searle A, Mathews M, et al. Analgesic efficacy of ultrasound-guided transversus abdominis plane block in patients undergoing open appendicectomy. $\mathrm{Br}$ J Anaesth 2009;103(4):601-5.

[16] Belavy D, Cowlishaw PJ, Howes M, et al. Ultrasound guided transversus abdominis plane block for analgesia after caesarean delivery. Br J Anaesth 2009;103(5):726-30.

[17] Costello JF, Moore AR, Wieczorek PM, et al. The transversus abdominis plane block, when used as a part of a multimodal regimen inclusive of intrathecal morphine, does not improve analgesia after caesarean delivery. Reg Anaesth Pain Med 2009;34(6):586-9.

[18] Manikar MG, Sardesai SP, Ghodki PS. Ultrasound guided transversus abdominis plane block for postoperative analgesia in patients undergoing caesarean section. Indian J Anaesth 2016;60(4):253-7.

[19] Saxena A, Gupta A, Mitra D, et al. To evaluate the efficacy of novel approach to transversus abdominis plane block for postoperative analgesia after abdominal surgeries. Saudi Surg J 2016;4(1):29-34.

[20] Papagiannopoulou P, Argiriadou H, Georgiou M, et al. Preincisional local infiltration of levobupivacaine versus ropivacaine for pain control after laparoscopic cholecystectomy. Surg Endosc 2003;17(12):1961-4.

[21] Mohamed AZEA. Assessment of the analgesic potency of ropivacaine $0.2 \%$ versus ropivacaine $0.5 \%$ in transversus abdominis plane block after caesarean delivery. Egyptian Journal of Anaesthesia 2016;32(3):385-90.
[22] Kabariety RE. Tramadol as an adjuvant to levobupivacaine in an ultrasound guided transversus abdominis plane block in women undergoing abdominal hysterectomy. Egyptian Journal of Anaesthesia 2013;6(3):304-11.

[23] Sinha S, Palta S, Saroa R, et al. Comparison of ultrasound-guided transversus abdominis plane block with bupivacaine and ropivacaine as adjuncts for postoperative analgesia in laproscopic cholecystectomies. Indian J Anaesth 2016;60(4):264-9.

[24] Salman IA, Kamel HS. A comparison between transversus abdominis plane block versus traditional parenteral analgesia post caesarean section: a prospective randomized double blind study. Iraqi Medical Journal 2012;11:718-23.

[25] Peterson PL, Hilsted KL, Dahl JB, et al. Bilateral transversus abdominis plane (TAP) block with 24 hours ropivacaine infusion via TAP catheters: a randomized trial in healthy volunteers. BMC Anaesthesiol 2013;13(1):30.

[26] Azawi NH, Mosholt KSS, Fode M. Unilateral ultrasound guided transversus abdominis plane block after nephrectomy: postoperative pain and use of opioids. Nephrourol Mon 2016;8(2):e35356.

[27] Venkatraman R, Abhinaya RJ, Sakthivel A, et al. Efficacy of ultrasound guided transversus abdominis plane block for postoperative analgesia in patients undergoing inguinal hernia repair. Local Reg Anaesth 2016;9:7-12.

[28] Yu N, Long X, Lujan-Hernandez JR, et al. Transversus abdominis plane block versus local anaesthetic wound infiltration in lower abdominal surgery: a systematic review and meta-analysis of randomized controlled trials. BMC Anaesthesiol 2014;14:121.

[29] Bhattacharjee S, Ray M, Ghose T, et al. Analgesic efficacy of transversus abdominis plane block in providing effective perioperative analgesia in patients undergoing total abdominal hysterectomy: a randomized controlled trial. J Anaesthesiol Clin Pharmacol 2014;30(3):391-6.

[30] Ortiz J, Suliburk JW, Wu K, et al. Bilateral transversus abdominis plane block does not decrease postoperative pain after laparoscopic cholecystectomy when compared with local anaesthetic infiltration of trocar insertion sites. Reg Anaesth Pain Med 2012;37(2):188-92. 